\title{
Seasonality of vespid species (Hymenoptera: Vespidae) in a central Brazilian cerrado
}

\author{
Ivone Rezende Diniz' and Kiniti Kitayama' \\ I Depto. deZoologia. Institutode Biologia.Universidade de Brasília. 70910-900 BrasíliaDF, Brasil.E-mail: zoo@guarany.unb.br
}

\author{
Received 31-X-1996. Corrected 23-X-1997. Accepted 03-XI-1997
}

\begin{abstract}
Foraging habitats as well as the fluctuations in vespid species" abundance in Mato Grosso State, Brazil, were determined, through sampling effort per hour per collector in four cerrado sensu lato habitats, "campo úmido" (Cu), "campo sujo" (Cs), "cerrado sensu stricto" (Css), and "gallery forest" (Mg), during four periods consisting of two dry (August 1988 and June 1989) and two wet (October and December 1988) season periods. For "campo úmido", some species seem to be highly seasonal, either in the dry or wet seasons, whereas very few species occur year-round. The abundance, species composition and richness varied between habitats types and between seasons.
\end{abstract}

Key words: Vespidae, foraging habitats, seasonality, cerrado, Brazil.

There is much evidence suggesting that seasonal fluctuations in insect abundance are commonplace in the tropics. Previous studies in tropical regions have shown an increase in insect abundance from the dry season to the wet season (e.g. Wolda 1978, Tanaka \& Tanaka 1982, Boinski \& Scott 1988, Frith \& Frith 1990). The major exceptions include some adult lepidopteran, bee, and Thysanoptera species (Owen \& Chanter 1970, Heithaus 1979, Boinski \& Scott 1988, Tanaka \& Tanaka 1982).

Taxonomically, the Vespidae of central Brazil are relatively well known, mainly because of the works done by Fox in 1898 who described 10 species, and of Richards (1978) who registered most vespid species (85) of central Brazil. However, their ecology and life histories are still very limited (Henriques et al. 1992, Ramos \& Diniz 1993, Diniz \& Kitayama 1994). Species seasonal composition for any animal group of the cerrado are also very poor known (Price et al. 1995).
The present work discusses the foraging habitats of vespid species and their seasonal activity in the Brazilian central cerradoat Chapada dos Guimarães, in Mato Grosso, during two dry and wet seasons.

\section{MATERIALS AND METHODS}

The work was carried out in Chapada dos Guimarães ( $155^{\circ} 30^{\prime} \mathrm{W} ; 14^{\circ} 52^{\prime} \mathrm{S}$, - Mato Grosso State in central Brazil) in four habitat types of cerrado sensu lato vegetation. They included: a wet grassland (campo úmido - $\mathrm{Cu}$ ), a scattered shrub area (campo sujo - Cs), a sparce shrubs and trees (cerrado sensu stricto - Css), and a gallery forest (Mata de galeria - Mg). All these varieties of cerrado (savanna) habitats have been detailed elsewhere (e.g. Eiten 1972, Diniz \& Kitayama 1994).

The region of cerrado is characterized by a wet season of five to seven months, with an average 
precipitation of around $200 \mathrm{~mm} / \mathrm{month}$, and a long dry season of about five months, from May to September, with a mean monthly precipitation of less than $30 \mathrm{~mm}$.

Vespids were collected during four series of collecting trips; the first three occurred in 1988, in August (end ofdry season), in October(beginning of wet season), and in December (middle of wet season). The last one occurred in June 1989 (beginning of dry season). In each habitat type a small area was selected of one to three ha in size for collecting wasps using an insect net. Each sampling period consisted of four hours of collection per collector, between seven to $11 \mathrm{a} . \mathrm{m}$. The total sample size for each habitat type was variable, with four $\mathrm{hr}$ in gallery forest, $12 \mathrm{hr}$ in "campo sujo" and $16 \mathrm{hr}$ in both "cerrado sensu stricto" and "campo úmido".

Voucher vespid species are deposited in the Entomology Collection of the Zoology Department of the University of Brasília.

\section{RESULTS}

Thirty six vespid species of the 50 sampled were collected in the four habitat types and used in the present work (Table 1). Polybia sericea (Olivier), P. ruficeps Schrotty, P. liliacea (F), Synoeca surinama $(\mathrm{L})$, Mischocyttarus drewseni de Saussure and Polistes subsericius de Saussure are the most abundant species in this region. Polistes liliaciosus de Saussure, known as an amazonian wasp, was registered for the first time in this region (Table 1).

Thirteen species (35.2\%) were restricted to one habitat type. "Campo úmido" and gallery forest were the habitats where a larger number of habitat-restricted species were encountered, but with a low number of individuals. Fifteen species $(40.5 \%)$ were collected in two habitat types, $18.9 \%$ in three, and $5.4 \%$ in four habitats (Table 1).

Fluctuations in abundance and species richness between seasons was determined only for those wasps collected in "campo úmido" due to the constancy of sample collections during the four sampleperiods. Fourvespid species werecollected only once, and during the wet season. Seven species were collected during both seasons, but the number of individuals collected was larger during the wet season than in the dry season (Table 2).

TABLE 1

Number of vespid species, and their occurrence in four habitat types in Mato Grosso state (Brazil)

\begin{tabular}{|c|c|c|c|c|c|c|}
\hline \multirow[b]{2}{*}{ Vespid species } & \multicolumn{6}{|c|}{ Habitat types } \\
\hline & $\mathrm{Cu}$ & Css & Cs & $\mathrm{Mg}$ & total & $\mathrm{H}$ \\
\hline Brachygastra augustii (de Saussure), 1854 & 6 & 0 & 2 & 0 & 8 & 2 \\
\hline B. bilineolata Spinola, 1841 & 4 & 0 & 0 & 0 & 4 & 1 \\
\hline B. lecheguana (Latreille), 1824 & 6 & 0 & 0 & 0 & 6 & 1 \\
\hline Chartegellus communis Richards, 1978 & 0 & 0 & 1 & 0 & 1 & 1 \\
\hline Chartergus chartarius (Olivier), 1791 & 0 & 0 & 0 & 3 & 3 & 1 \\
\hline Epipona tatua (Curvier), 1797 & 0 & 1 & 0 & 5 & 6 & 2 \\
\hline Mischocyttarus cerberus Ducke, 1918 & 0 & 6 & 0 & 0 & 6 & I \\
\hline M. drewseni de Saussure, 1857 & 50 & 0 & 0 & 0 & 50 & 1 \\
\hline
\end{tabular}


Vespid species

M. rotundicolis (Cameron), 1912

M. matogrossoensis Zikán, 1935

Parachartegus fraternus (Gribodo), 1892

P. smithii (de Saussure), 1854

P. billardieri F. 1804

P. geminatus Fox, 1898

P. subsericius de Saussure, 1854

P. thoracicus Fox, 1898

Polybia jurinei de Saussure, 1854

P. dimidiata (Olivier), 1791

P. quadricincta de Saussure, 1854

P. erythrothorax Richards, 1978

P. flavifrons F. Smith, 1857

P. occidentalis Olivier, 1791

P. ruficeps Schrottky, 1902

P. Liliacea (F.) 1804

P. chrysothorax (Lichtenstein), 1796

P. ignobilis (Holiday), 1791

P. sericea (Olivier), 1791

Protopolybia exigua (de Saussure), 1854

Pseudopolybia compressa (de Saussure), 1854

Stelopolybia flavipennis (Ducke), 1905

S. Iobipleura Richards, 1987

S. multipicta (Holiday), 1836

S. myrmecophila (Ducke), 1905

S. pallipes (Olivier), 1791

Synoeca surinama (L.), 1767

Total of species and (individuals)
Polistes canadensis (L.) 1804

\section{Habitat types}

\begin{tabular}{|c|c|c|c|c|}
\hline $\mathrm{Cu}$ & Css & Cs & $\mathrm{Mg}$ & total \\
\hline 20 & 0 & 1 & 0 & 21 \\
\hline 18 & 1 & 1 & 0 & 20 \\
\hline 0 & 1 & 2 & 11 & 14 \\
\hline 1 & 0 & 0 & 0 & 1 \\
\hline 12 & 3 & 1 & 0 & 16 \\
\hline 3 & 1 & 0 & 0 & 4 \\
\hline 1 & 1 & 0 & 0 & 2 \\
\hline 47 & 3 & 3 & 0 & 53 \\
\hline 0 & 1 & 0 & 0 & 1 \\
\hline 0 & 3 & 0 & 2 & 5 \\
\hline 0 & 7 & 6 & 0 & 13 \\
\hline 1 & 1 & 0 & 0 & 2 \\
\hline 5 & 3 & 4 & 0 & 12 \\
\hline 0 & 0 & 0 & 5 & 5 \\
\hline 1 & 0 & 0 & 4 & 5 \\
\hline 10 & 3 & 0 & 18 & 31 \\
\hline 0 & 3 & 4 & 21 & 28 \\
\hline 0 & 0 & 0 & 1 & 1 \\
\hline 0 & 3 & 6 & 0 & 9 \\
\hline 5 & 6 & 9 & 2 & 22 \\
\hline 3 & 0 & 0 & 5 & 8 \\
\hline 0 & 0 & 0 & 1 & 1 \\
\hline 0 & 0 & 3 & 1 & 4 \\
\hline 0 & 4 & 0 & 0 & 4 \\
\hline 0 & 3 & 3 & 0 & 6 \\
\hline 0 & 0 & 1 & 1 & 2 \\
\hline 0 & 0 & 1 & 0 & 1 \\
\hline 3 & 2 & 1 & 4 & 10 \\
\hline $196(18)$ & $56(20)$ & $49(17)$ & $84(15)$ & $385(36)$ \\
\hline
\end{tabular}

$\mathrm{Cu}=$ campo úmido; $\mathrm{Css}=$ cerrado sensu stricto; $\mathrm{Cs}=$ campo sujo; $\mathrm{Mg}=$ mata de galeria (gallery forest); $\mathrm{H}=$ number of habitats where wasps were collected. 
TABLE 2

Species of vespid collected in campo úmido during four sample periods, and species abundance and richness for each habitat type in Mato Grosso state (Brazil).

Species of vespid

Brachygastra augustii (de Saussure), 1854

B. bilineolata Spinola, 1841

B. lecheguana (Latreille), 1824

Mischocyttarus drewseni de Saussure, 1857

M. rotundicolis (Cameron), 1912

M. matogrossoensis Zikán, 1935

Parachartegus smithii (de Saussure), 1854

Polistes canadensis (L.) 1804

P. billardieri F. 1804

P. geminatus Fox, 1898

P. subsericius de Saussure, 1854

Polybia quadricincta de Saussure, 1854

P. erythrothorax Richards, 1978

P. occidentalis Olivier, 1791

P. ruficeps Schrottky, 1902

P. sericea (Olivier), 1791

Protopolybia exigua (de Saussure), 1854

Synoeca surinama (L.), 1767

Total Cu (16 hours) Species/Specimens

Total Cs (12 hours) Species/Specimens

Total Css (12 hours) Species/Specimens

Total Mg (04 hours) Species/Specimens

\begin{tabular}{|c|c|c|c|c|}
\hline Aug./88 & Oct./88 & Dec./88 & une/89 & Total \\
\hline 0 & 4 & 2 & 0 & 6 \\
\hline 1 & 2 & 0 & 1 & 3 \\
\hline 0 & 1 & 1 & 4 & 6 \\
\hline 7 & 6 & 30 & 7 & 50 \\
\hline 2 & 0 & 18 & 0 & 20 \\
\hline 0 & 3 & 8 & 7 & 18 \\
\hline 0 & 1 & 0 & 0 & 1 \\
\hline 6 & 1 & 5 & 0 & 12 \\
\hline 0 & 0 & 1 & 2 & 3 \\
\hline 0 & 1 & 0 & 0 & 1 \\
\hline 1 & 3 & 21 & 22 & 47 \\
\hline 0 & 0 & 1 & 0 & 1 \\
\hline 0 & 4 & 1 & 0 & 5 \\
\hline 0 & 1 & 0 & 0 & 1 \\
\hline 0 & 7 & 1 & 2 & 10 \\
\hline 1 & 2 & 2 & 0 & 5 \\
\hline 0 & 3 & 0 & 0 & 3 \\
\hline 1 & 1 & 1 & 0 & 3 \\
\hline $7 / 19$ & $15 / 40$ & $13 / 92$ & $7 / 45$ & $18 / 196$ \\
\hline $11 / 21$ & $5 / 10$ & $9 / 18$ & $*$ & $17 / 49$ \\
\hline$*$ & $2 / 24$ & $4 / 6$ & $14 / 26$ & $20 / 56$ \\
\hline $15 / 84$ & * & * & * & $15 / 84$ \\
\hline
\end{tabular}

* not sampled; $\mathrm{Cu}=$ campo úmido; $\mathrm{Css}=$ cerrado sensu stricto; $\mathrm{Cs}=$ campo sujo; $\mathrm{Mg}=$ mata de galeria (gallery forest) 
At the end of dry season (August), $81.5 \%$ of the vespid species were collected in only one habitat, $7.5 \%$ in both two and three habitat types. At the beginning of the wet season (October), $68.2 \%$ of the species were collected in one habitat, $18.2 \%$ in two, and $13.6 \%$ species were captured in all three habitats: M. matogrossoensis, Polistes subsericius and Polybia sericea . At the middle of the wetseason $73.7 \%$ ofthe species were captured in one habitat, $15.8 \%$ in two, and two species, Polistes canadensis and Polistes subsericius, were collected in all three habitats. At the beginning of the dry season (June), only "campo úmido" and "cerrado sensu stricto" were sampled. Seventeen species $(89.5 \%)$ were collected in one kind of habitat: of these, $63.2 \%$ in cerrado sensu stricto and $26.3 \%$ in "campo úmido". Two species were collected in both: Polistes subsericius and Polybia ruficeps. $P$. subsericius occurs in all habitattypes while foraging, during all seasons, but its nesting habitat is 'campo úmido' where it constructs its nest at the base of the grass (pers. obs.).

Comparing the Shannon diversityindex among habitattypes andsampling periods, "cerradosensu stricto" presented the highest diversity index during the dry season $\left(\mathrm{H}^{\prime}=1.004\right.$ in August $1988)$ and $\left(\mathrm{H}^{\prime}=1.035\right.$ in June 1989) while "campoúmido" at the beginning of the wetseason $\left(\mathrm{H}^{\prime}=1.080\right.$ in October 1988), and "campo sujo" at the middle of the wet season $(\mathrm{H}=0.849$ in December 1988). The gallery forest presented in the dry season (August) the highest number of species but also the highest abundance what reflected in the diversity index $\left(\mathrm{H}^{\prime}=0.058\right)$. Most of the coefficients of similarity (Bray \& Curtis) were small (less than 0.10 ). The highest similarity index was found between "cerrado sensu stricto" and "campo sujo" (0.530) at the beginning of wet season (October).

\section{DISCUSSION}

The 50 species represent an increase of 39 species if compared with Richards's (1978) numbers for this region (11 species). In spite of the poor sampling of gallery forest (only four hours - one collector) and the sampling areas and restricted periods, the result may be considered very representative, since $43 \%$ of the known species of the whole state were collected.

The results shows that even for vespids, supposedly good flyers, a restriction in habitat occurs (Table 1). Few species that nest in one habitat may hunt theirpreys or seek waterin other habitats. Suchexceptionsinclude Mischocyttarus mattogrossoensis Zikán, Polistes canadensis (L), and $P$. subsericius which nest in "campo úmido" (Diniz \& Kitayama 1994) and forage in cerrado sensu stricto and "campo sujo"; Polybia sericea, which nests incerrado sensustricto, and Synoeca surinama, which nests in gallery forest, and were found foraging in all four habitats studied. Indeed, these last two wasp species are large and robust, therefore they can fly a longer distance from their nests.Mischocyttarusdrewseni was captured only in its nesting habitat (Table 1).

The abundance and species richness in the dry season in "campo úmido" (64 individuals of 11 species) were much smaller than that found during the wet season (132 individuals of 18 species) (Table 2). Similar results were obtained for other tropical regions (e. g. Tanaka \& Tanaka 1982, Boinski \& Scott 1988).

Gallery forest appears to be the most favorable habitat for wasps during the dry season, with larger numbers of species (63\%) and individuals $(70 \%)$. This result agrees with the argument that gallery forest "act as nucleus for re-colonization of deciduous habitat" (Forsyth 1980). Foraging habitats seem to vary between dry and wet seasons. Indeed, at least in "campo úmido", during the wet season, the number of species and specimens captured was asmuchastwicethat whichoccurred during the dry season.

The results show evidence of the extreme importance of the moist habitats, for the maintenance of vespid colonies during the long dry season in the "cerrado" area. Therefore, is it necessary to preserve all kinds of habitats in the 
cerrado, mainly due to the faunal spatial and temporal variation, and especially because many species use only a specific habitat for nesting, usually which is more restricted than its foraging habitat.

\section{ACKNOWLEDGMENTS}

This research was financed by the electrical Brazilian company (Eletronorte). We are grateful to Regina Macedo (University of Brasília), and two reviewers of the Revista de Biologia Tropical for important suggestions to improve the manuscript.

\section{REFERENCES}

Boinski, S. \& P. E. Scott. 1988. Association of birds with monkeys in Costa Rica. Biotropica 20: 138-143.

Diniz, I. R. \& K. Kitayama. 1994. Colony densities and preferences for nest habitats of some social wasps in Mato Grosso State, Brazil (Hymenoptera Vespidae). J. Hym. Res. 3: 133-143.

Eiten, G. 1972. The Cerrado vegetation of Brazil. Bot. Rev. 38: 201-341.

Forsyth, A. 1980. Nest site and habitat selection by the social wasp, Metapolybia azteca Araujo (Hymenoptera: Vespidae) Brenesia 17: 157-162.
Frith, D. \& C. Frith. 1990. Seasonality of litter invertebrate populations in an Australian upland tropical rain forest. Biotropica 22: 181-190.

Heithaus, E. R. 1979. Community of neotropical flower visiting bees and wasps: diversity and phenology. Ecology 60: $190-202$

Henriques, R. P. B., I. R. Diniz \& K. Kitayama. 1992. Nest density of some social wasp species in cerrado vegetation of central Brazil (Hymenoptera: Vespidae). Entomol. Gen. 17: 265-268.

Owen, D. F. \& D. O. Chanter.1972. Species diversity and seasonal abundance in Charaxes butterflies (Nymphalidae). J. Entomol. 46: 135-143.

Price, P. W., I. R. Diniz, H. C. Morais \& E. S. Marques. 1995. The abundance of insect herbivore species in the tropics: The high richness of rare species. Biotropica 27: 468-478.

Ramos, F. A.\& I. R. Diniz. 1993. Seasonalcycles, survivorship and growth of colonies of Polistes versicolor (Hymenoptera-Vespidae) in the urban area of Brasília Brazil. Entomologist 112: 191-200.

Richards, O. W. 1978. The social wasps of the Americas. British Museun of Natural History. London 580 p.

Tanaka, L. K. \& S. K. Tanaka. 1982. Rainfall and seasonal changes in Arthropoda abundance on a tropical oceanic island. Biotropica 14: 114-123.

Wolda, H. 1978. Seasonal fluctuations in rainfall, food and abundance of tropical insects. J. Anim. Ecol. 47: 369-381. 